\title{
ANALISIS USAHA DAN PEMASARAN MADU KELULUT DI KABUPATEN KAMPAR
}

\author{
Analysis of Business and Marketing of Kelulut Honey in Kampar Regency
}

\author{
Sisca Vaulina dan Sri Ayu Kurniati \\ Fakultas Pertanian Universitas Islam Riau. Jl. Kaharuddin Nasution 113, Pekanbaru 28284 Riau \\ Email: siscavaulina@agr.uir.ac.id \\ [Diterima: November 2019; Disetujui: Desember 2019]
}

\begin{abstract}
Bee breeding is a side job and source of income for local population. The research objectives were to analyze the characteristics breeders and business profile of kelulut honey, to know the kelulut honey cultivation technology, recognize the rocessing (agroindustry) of kelulut honey, determine the production costs, production, income, and efficiency of kelulut honey, and analysis the marketing of kelulut honey in Kampar regency. This study used a survey method. The sample was selected by purposive sampling as 26 breeders. Data were analyzed qualitative and quantitative descriptive approaches. The results showed that the characteristics of the breeders were in the productive age category (26-55 years old), SD-Bachelor education and breeding experience between 1-6 years. The business was established in 2016 with the name of "Kelompok Madu Galo-Galo Kuok Lestari". The breeders have 2-40 bee boxes and use family labor. Technology of breeding kelulut honey consisted of a parent colony, colony splitting, manufacture and placement of hive, maintenance, and harvesting. The processing was traditional. Kelulut honey required a production cost of IDR $487,883.33$ /production process, produce an average production of 20.04 liters during the flowering season and the non-flowering season 7.79 liters. The average net income derived each harvesting as IDR 2,973,655.13/breeder/boxe and IDR 858,270.52/ breeders/boxe during on flower season and off season, respectively. Kelulut honey marketing only sells to the city of Pekanbaru.
\end{abstract}

Keywords: Kelulut honey, Income, Marketing

\begin{abstract}
ABSTRAK
Beternak lebah merupakan pekerjaan sampingan peternak dan merupakan sumber pendapatan penduduk lokal. Tujuan penelitian untuk menganalisis karakteristik peternak madu kelulut dan profil usaha madu kelulut, mengetahui teknologi budidaya madu kelulut, mengetahui proses pengolahan (agroindustri) madu kelulut, mengetahui biaya produksi, produksi, pendapatan dan efisiensi madu kelulut dan menganalisis pemasaran madu kelulut di Kabupaten Kampar. Penelitian ini menggunakan metode survey. Sampel ditentukan berdasarkan purposive sampling sebanyak 26 orang peternak. Data dianalisis dengan menggunakan deskriptif kualitatif dan deskriptif kuantitatif. Hasil penelitian menunjukkan bahwa karakteristik peternak dengan kategori umur produktif (26-55 thun), pendidikan SD-Sarjana dan pengalaman beternak 1-6 tahun. Profil usaha dirintis pada tahun 2016 dengan nama kelompok madu galo-galo kuok lestari yang beranggota sebanyak 26 orang peternak dengan jumlah kotak lebah masin-gmasing 2 - 40 buah,dan menggunakan tenaga kerja dalam keluarga. Teknologi budidaya terdiri dari mendapatkan koloni induk; pemindahan koloni/pemecahan koloni; pembuatan dan penempatan stup; pemeliharaan dan pemanenan. Proses pengolahan bersifat tradisional. Usaha madu kelulut membutuhkan biaya produksi Rp. 487.883,33/proses produksi; dengan rata-rata produksi madu pada saat musim berbunga 20,04 liter dan pada saat tidak musim berbunga 7,79 liter. Rata-rata pendapatan bersih pada musim bunga sebesar Rp 2.973.655,13 per orang per panen per kotak lebah dan pada saat tidak musim bunga Rp 858.270,52 per orang per panen per kotak lebah. Pemasaran madu kelulut hanya menjual ke kota Pekanbaru.
\end{abstract}

Kata kunci: Madu Kelulut, Pendapatan, Pemasaran 


\section{PENDAHULUAN}

Kebijakan pembangunan kehutanan dewasa ini mulai bergeser dari pemanfaatan hutan menjadi pelestarian fungsi hutan. Pengelolaan sumber daya hutan selama ini cenderung berorientasi pada timber based management yang hanya menekankan pada pengelolaan hasil kayu. Paradigma baru pengelolaan sumber daya hutan pada masa mendatang tidak semata-mata menggunakan pendekatan produksi saja, tetapi sudah dilakukan dengan pola manajemen sumber daya alam (Resource Based Management) yang mensinergikan antara aspek ekologi, ekonomi dan sosial masyarakat melalui pendekatan pembangunan yang berpihak pada masyarakat (Community Based Development). Pendekatan Community Based Development dapat memberikan berbagai manfaat tidak hanya berfokus pada kayu, namun juga dikembangkan hasil hutan bukan kayu yang salah satunya adalah perlebahan (Kementrian Kehutanan, 2012).

Madu adalah cairan kental yang dihasilkan oleh lebah madu (Apis sp.) dari nektar bunga atau bagian lain dari tanaman (Sumoprastowo dan Agus, 1993). Kegiatan pengembangan ternak lebah madu khususnya madu kelulut skala rakyat sudah dilakukan di Kabupaten Kampar Provinsi Riau. Daerah ini sangat baik bagi pengembangan lebah madu kelulut yang ditandai dengan $85 \%$ dari luas lahan merupakan perkebunan yang menghasilkan tanaman bunga sebagai sumber pakan lebah madu, adanya sumber air yang dibutuhkan lebah madu dan adanya bahan pembuatan sarang yang mudah untuk didapatkan. Potensi ini menjadi lebih baik lagi dimana sebagian penduduk berprofesi sebagai peternak madu.

Saat ini peternak lebah masih melakukan budidaya dengan teknologi tradisional, memiliki permodalan terbatas, dan sulit memasarkan produk karena produk yang dihasilkan tidak sesuai dengan permintaan pasar. Usaha perlebahan mampu meningkatkan pemberdayaan ekonomi rakyat terutama kesejahteraan masyarakat di sekitar hutan. Dengan demikian, mereka dapat berpartisipasi dalam pelestarian hutan dan lingkungan. Badan Penelitian dan Pengembangan Kehutanan (2012), manfaat yang dapat diperoleh dari kegiatan pengembangan perlebahan antara lain dapat meningkatkan pendapatan dan mutu gizi masyarakat dari hasilhasil perlebahan seperti madu, tepung sari, royal jelly, lilin lebah, propolis.

Kegiatan pengembangan ternak lebah madu kelulut skala rakyat selalu mengalami kendala berupa produktivitas yang rendah. Salah satu faktor penyebabnya adalah karena kurangnya kesungguhan peternak dalam beternak lebah madu. Hal ini karena beternak lebah merupakan pekerjaan sampingan bagi penduduk setempat. Dengan demikian akan berdampak terhadap penerimaan yang akan diperoleh oleh peternak. Oleh sebab itu, perlu dilakukan analisis usaha dan pemasaran agar peternak lebih antusias untuk mengembangkan usahanya. Berdasarkan hal tersebut, maka tujuan penelitian untuk mengetahui dan menganalisis: (1) Karakteristik peternak madu kelulut dan profil usaha madu kelulut di Kabupaten Kampar (2) Teknologi budidaya madu kelulut di Kabupaten Kampar (3) Proses pengolahan (agroindustri) madu kelulut di Kabupaten Kampar (4) Biaya produksi, produksi, pendapatan dan efisiensi madu kelulut di Kabupaten Kampar (5) Pemasaran madu kelulut di Kabupaten Kampar.

\section{METODOLOGI PENELITIAN}

Penelitian ini menggunakan metode survey. Penelitian diawali dengan menentukan lokasi-lokasi penelitian (kecamatan) berdasarkan sentra produksi lebah madu kelulut. Data yang digunakan dalam penelitian ini meliputi data primer dan data sekunder. Sampel ditentukan berdasarkan purposive sampling, dengan kriteria bahwa peternak madu kelulut rakyat yang kontinuitas memproduksi madu. Di Kabupaten Kampar, sentra produksi madu kelulut di Kecamatan Kuok, tepatnya di Desa Kuok, Desa Tambang, Rumbio, Salo dan Air Tiris. Dengan demikian, jumlah sampel penelitian sebanyak 26 orang.

\section{Analisis Data}

Adapun analisis data yang digunakan dalam penelitian ini dapat dijelaskan sebagai berikut:

\section{Karakteristik Peternak dan Profil Madu Kelulut}

Untuk menganalisis karakteristik petani akan dijelaskan dengan mendeskripsikan umur, pendidikan, jumlah tanggungan keluarga dan pengalaman berusahatani dengan pendekatan deskriptif kualitatif dan deskriptif kuantitatif. 


\section{Budidaya Madu Kelulut}

Untuk menganalisis budidaya madu kelulut akan dijelaskan dengan pendekatan deskriptif kualitatif dan deskriptif kuantitatif, lalu diinterpretasikan menggunakan tabel atau gambar serta dibandingkan teori budidaya madu kelulut dengan budidaya yang dilakukan oleh peternak madu kelulut.

\section{Usahatani Madu Kelulut}

\section{A. Biaya}

Untuk mengetahui besarnya biaya yang dikeluarkan, digunakan perhitungan:

$\mathrm{TC}=\mathrm{FC}+\mathrm{VC}$

Keterangan:

$\mathrm{TC}=$ Total Cost (Biaya Total)

$\mathrm{FC}=$ Fixed Cost (Biaya Tetap)

$\mathrm{VC}=$ Variabel Cost (Biaya Variabel $)$

\section{B. Produksi}

Untuk produksi madu kelulut digunakan analisis deskriptif, dengan cara memaparkan atau mendeskripsikan dan dibuat dalam bentuk tabel, produksi yang diperoleh petani dibandingkan dengan teori.

\section{Pendapatam}

Pendapatan dapat diperoleh dengan cara mengurangkan pendapatan total (TR) dan biaya total (TC).

$\pi=\mathrm{TR}-\mathrm{TC}$

\section{Keterangan:}

$\Pi \quad=$ Pendapatan Bersih

TR = Pendapatan total (Total Revenue)

TC = Biaya total (Total Cost)

Peralatan yang digunakan pada usahatani kelapa dalam umumnya tidak habis dipakai untuk satu kali periode produksi (lebih dari satu tahun). Oleh karena itu, biaya peralatan yang dihitung sebagai komponen biaya produksi adalah nilai penyusutannya. Untuk menghitung besarnya biaya penyusutan alat yang digunakan yakni metode garis lurus (straight line method) yang dikemukakan oleh Hernanto (1996), dengan rumus:

$\mathrm{D}=\frac{\mathrm{C}-\mathrm{SV}}{\mathrm{UL}}$

Keterangan:

D : Biaya penyusutan (Rp/unit/tahun)

C : Harga beli (Rp/unit/tahun)

SV : Nilai sisa $20 \%$ dari harga beli (Rp/unit/tahun)
UL : Masa pakai alat (tahun)

D. Efisiensi

Efisiensi usahatani madu kelulut dianalisis menggunakan pendekatan Return Cost Ratio (RCR). Effendi dan Oktariza (2006) dalam Ngamel (2012), menjelaskan bahwa analisis Revenue Cost Ratio (R/C Rasio) merupakan alat analisis untuk melihat keuntungan relatif suatu usaha dalam satu tahun terhadap biaya yang dipakai dalam kegiatan tersebut. Kriteria yang digunakan dalam analisis $\mathrm{R} / \mathrm{C}$ rasio sebagai berikut:

- Jika nilai R/C rasio > 1 usaha dikatakan layak dan menguntungkan

- Jika nilai R/C rasio < 1 usaha dikatakan tidak layak dan tidak menguntungkan

- Jika nilai $\mathrm{R} / \mathrm{C}$ rasio = 1 usaha dikatakan impas (tidak untung dan tidak rugi).

Dengan rumus sebagai berikut:

$\mathrm{RCR}=\frac{\mathrm{TR}}{\mathrm{TC}}$

Keterangan:

$\mathrm{RCR}=$ Return Cost Ratio

$\mathrm{TR}=$ Pendapatan kotor $(\mathrm{Kg} / \mathrm{panen})$

$\mathrm{TC}=$ Total biaya produksi $(\mathrm{Kg} / \mathrm{panen})$

Dengan kriteria;

RCR $>1$ = Berarti usahatani madu kelulut menguntungkan

RCR $<1=$ Berarti usahatani madu kelulut tidak menguntungkan

$\mathrm{RCR}=1$ = Berarti usahatani madu kelulut berada pada titik impas

\section{Proses Pengolahan Madu Kelulut}

Untuk mendeskripsikan proses pengolahan madu kelulut dengan cara diinterpretasikan melalui tabel atau gambar.

\section{Pemasaran Madu Kelulut}

Untuk menganalisis pemasaran madu kelulut dapat dianalisa dengan deskriptif kualitatif, mendiskripsikan mengenai penjualan madu dari peternak madu.

\section{HASIL DAN PEMBAHASAN}

\section{Karakteristik Peternak dan Profil Usaha Madu Kelulut}

\section{A. Karakteristik Peternak}

Karakteristik peternak pada penelitian ini dilihat dari (1) Umur, (2) Pendidikan, (3) Pengalaman beternak. Secara rinci dapat dilihat pada Tabel 1. 
Tabel 1. Karakteristik Peternak Berdasarkan Umur, Pendidikan dan Pengalaman Beternak, Tahun 2019

\begin{tabular}{|c|c|c|c|}
\hline No & Uraian & Jumlah (Orang) & Persentase $(\%)$ \\
\hline \multirow[t]{5}{*}{1} & Umur & & \\
\hline & $26-35$ & 7 & 26,92 \\
\hline & $36-45$ & 14 & 53,85 \\
\hline & $46-55$ & 5 & 19,23 \\
\hline & Jumlah & 26 & 100,00 \\
\hline \multirow[t]{6}{*}{2} & Pendidikan & & \\
\hline & SD & 5 & 19,23 \\
\hline & SMP & 6 & 23,08 \\
\hline & SMA/SMK & 11 & 42,31 \\
\hline & Sarjana & 4 & 15,38 \\
\hline & Jumlah & 26 & 100,00 \\
\hline \multirow[t]{5}{*}{3} & Pengalaman Beternak & & \\
\hline & $1-2$ & 5 & 19,23 \\
\hline & $3-4$ & 15 & 57,69 \\
\hline & $5-6$ & 6 & 23,08 \\
\hline & Jumlah & 26 & 100,00 \\
\hline
\end{tabular}

1) Umur

Umur merupakan faktor terpenting dalam kegiatan beternak, karena tingkat produktivitas peternakan dipengaruhi oleh kematangan fisik dan mental yang kuat atas pekerjaan pada saat seseorang telah memasuki usia produktif. Sesuai dengan pernyataan Mubyarto (1986), petani atau peternak yang berada pada usia produktif akan memberikan hasil kerja yang maksimal jika dibandingkan dengan usia yang tidak produktif.

Mubyarto (1989), petani atau peternak yang berada pada usia produktif berkisar antara 15-64 tahun. Seluruh peternak lebah madu di Kabupaten Kampar dengan kategori usia produktif, umur 26-35 tahun berjumlah 7 orang peternak (26,92 \%), umur 36-45 tahun berjumlah 14 peternak $(53,85 \%)$, umur $46-55$ tahun berjumlah 5 peternak $(19,23 \%)$.

\section{2) Pendidikan}

Pendidikan peternak lebah madu kelulut di Kecamatan Kampar mulai dari SD, SMP, SMA/SMK dan Sarjana. Pendidikan tertinggi pada peternak lebah madu adalah Sarjana. Beternak lebah madu tentu ada kaitannya dengan tingkat pendidikan karena semakin tinggi pendidikan maka semakin banyak pula ilmu yang didapatkan oleh para peternak dalam memelihara dan membudidayakan lebah madu dengan sistem yang lebih modern tentunya. Tingkat pendidikan secara tidak langsung akan mempengaruhi kemampuan peternak dalam menerima atau mengadopsi informasi dan penerapannya.
Menurut Mosher (1977) bahwa tingkat pendidikan yang rendah pada umumnya akan menghambat masuknya suatu inovasi baru. Namun disini tidak menutup kemungkinan bahwa tingkat pendidikan terendah sekalipun juga dapat membudidayakan lebah madu dengan sangat baik dengan mengikuti kegiatan atau sosialisasi yang diadakan disetiap desa yang membahas tentang tata cara pembudidayaan lebah madu dengan baik serta mengikuti prosedur yang berlaku.

Pada Tabel 1, dapat dilihat bahwa peternak madu memiliki pendidikan Sekolah Dasar berjumlah 5 orang $(19,23 \%)$; SMP berjumlah 6 orang $(23,08 \%)$; SMA/SMK berjumlah 11 orang $(42,31 \%)$ dan Sarjana 4 orang $(15,38 \%)$.

\section{3) Pengalaman Beternak}

Pengalaman usaha merupakan faktor yang cukup menentukan bagi kelangsungan usaha yang digeluti. Pengalaman beternak akan menjadi modal untuk menentukan apa yang akan dilakukan agar kegagalan, kerugian dan hal negatif yang dapat merugikan para peternak tidak terulang. Mubyarto (1986), pengalaman beternak yang berbeda antar peternak akan menunjukkan cara yang berbeda dalam pengambilan keputusan dalam beternak lebah madu serta pengalaman tersebut akan membuat peternak dapat lebih mempelajari lagi cara beternak sesuai dengan pengalaman sebelumnya sehingga tingkat produktivitas dapat meningkat.

Usaha peternakan lebah madu di daerah penelitian dapat dikatakan sudah berpengalaman terhadap budidaya madu 
kelulut, mereka sudah bertahun-tahun menggeluti usaha ternak lebah madu kelulut. Pengalaman beternak lebah madu 1-2 tahun berjumlah 5 peternak $(19,23 \%)$; 3-4 tahun berjumlah 15 peternak $(57,69 \%)$; dan 5-6 tahun berjumlah 6 peternak $(23,08 \%)$. Semakin lama pengalaman berternak maka akan semakin meningkat pula pengetahuan atau pengalaman yang didapat tentang cara berternak lebah madu yang baik, terutama mengenai klonning lebah (perbanyakan lebah).

\section{B. Profil Usaha Madu Kelulut}

Usaha madu galo-galo ini dirintis pada awal tahun 2016 oleh pak Safran (36 tahun), dengan cara coba-coba dan mengandalkan informasi dari media sosial. Melihat potensi perkembangan pembudidayaan dan pemasarannya, pada pertengahan tahun 2017, pak Safran membentuk kelompok madu galogalo kuok lestari yang beranggotakan 16 orang. Saat ini, anggota kelompok madu galogalo memiliki kotak lebah (stup) berkisar antara 2-40 kotak lebah. Usaha madu galo-galo ini sepenuhnya dilakukan sendiri oleh keluarga. Petani menggunakan tenaga kerja dari dalam keluarga, terdiri dari anak, istri dan suami.

Pada umumnya, beternak lebah bukan merupakan matapencaharian utama (matapencaharian pokok) peternak setempat. Karyawan swasta dan PNS merupakan matapencaharian utama peternak lebah. Dapat dilihat pada Gambar 1.

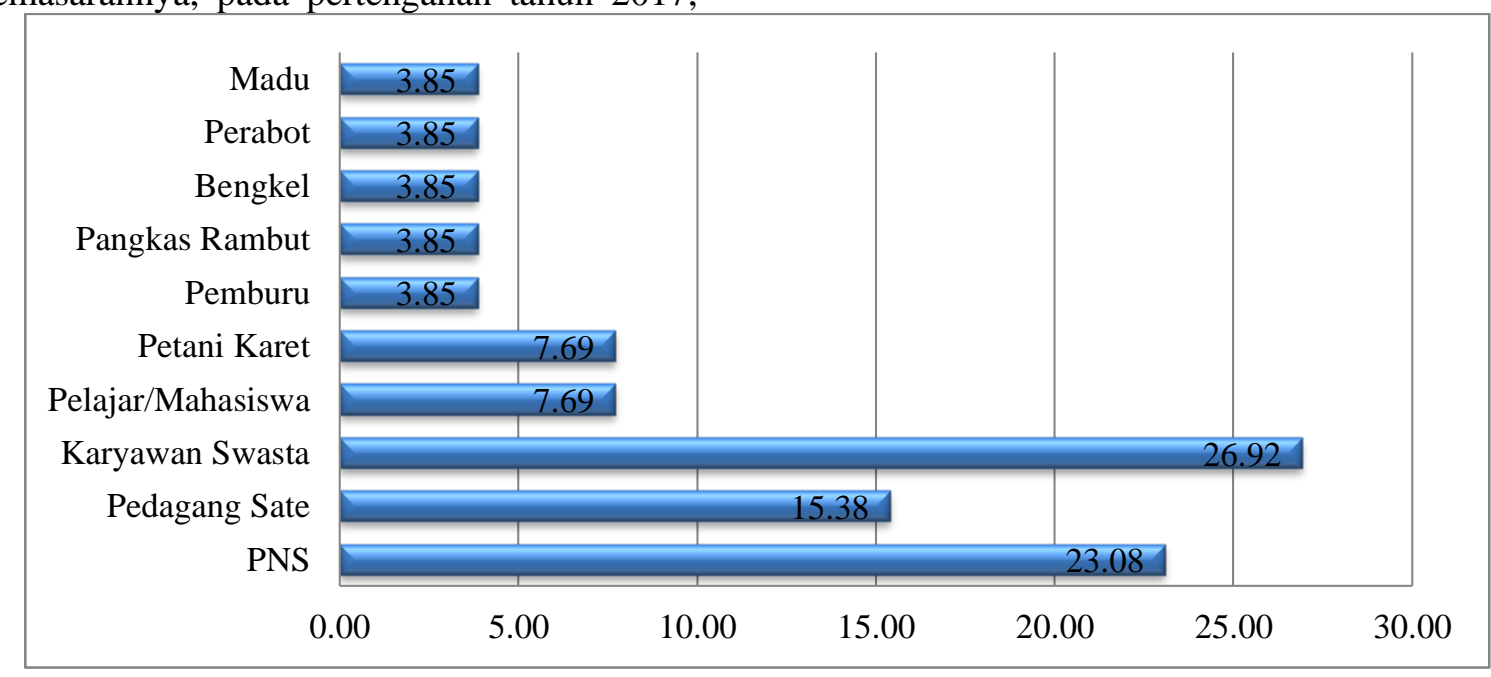

Gambar 1. Matapencaharian Utama Peternak Lebah di Kabupaten Kampar, Tahun 2019

Ditinjau dari kedudukan usaha membudidayakan lebah madu kelulut dalam ekonomi keluarga, beternak hanya menjadi usaha sampingan dikalangan para peternak. Pada Gambar 1 terlihat bahwa 1 sampel $(3,85 \%)$ yang matapencaharaian utamanya sebagai peternak lebah madu. Hal tersebut disebabkan karena jumlah lebah yang dipelihara masih relatif sedikit dengan sistem pemeliharaan yang masih bersifat tradisional. Keadaan tersebut tidak memungkinkan untuk menjamin kontinuitas sistem produksi dan pemasaran madu secara terencana dan terproduksi dengan baik.

Kotak lebah diletakkan di pekarangan rumah dan di pepohonan penghasil nektar. Peternak umumnya membeli koloni lebah, dan selanjutnya membuat sendiri kotak lebah. Sehingga jenis kotak lebah bervariasi. Hingga saat ini, kelompok belum bisa membuat klonning lebah (pecah koloni) dari koloni lebah yang telah dibeli tersebut. Harga koloni lebah berkisar Rp 150.000/koloni-Rp 350.000/koloni, sedangkan jika sudah berbentuk kotak lebah, harga berkisar Rp 400.000/kotak-Rp 800.000/kotak. (Gambar 2).

Spesies lebah galo-galo yang diusahakan adalah jenis Itama dan Thoracica, karena kedua jenis lebah ini paling sesuai dengan kondisi lingkungan Desa Kuok. Vegetasi sebagai pakan lebah terdiri dari tanaman bunga: kaliandra merah, air mata pengantin, xanthostemon kuning dan luciana. Tanaman buah; durian, rambutan dan jambu. Begitu juga dengan tanaman karet dan akasia. Panen raya terjadi ketika musim bunga, yaitu dimulai 
bulan Juli-desember setiap tahunnya (6 bulan). Ketika musim bunga, produksi madu bisa mencapai $800 \mathrm{ml}-1$ liter/kotak madu/bulan,

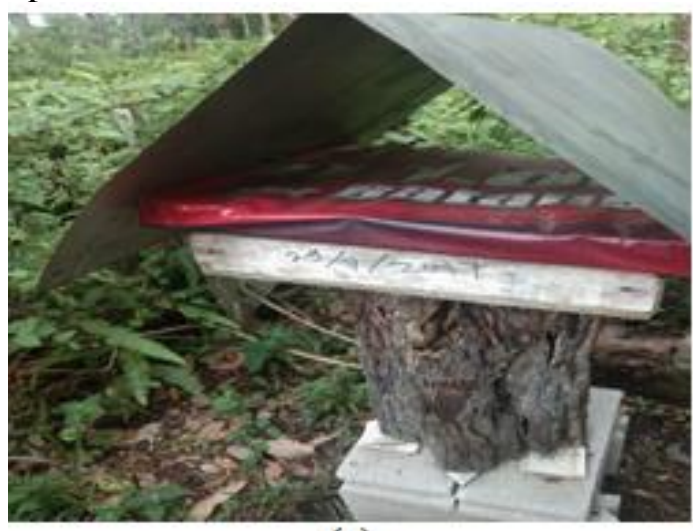

(a) sedangkan tidak musim bunga $200 \mathrm{ml}-500 \mathrm{ml}$ /kotak madu/bulan.

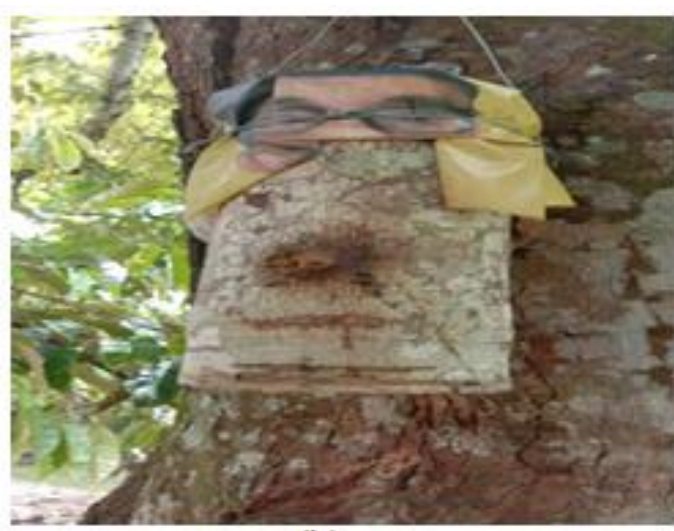

(b)

Gambar 2. (a) Kotak Lebah (Stup), (b) Koloni Lebah Tanpa Toping

Banyaknya stup tergantung pada jumlah koloni lebah yang dimiliki peternak. Setiap koloni terdiri atas ratu, pejantan dan lebah pekerja, sehingga setiap stup mewadahi satu koloni lebah. Besarnya koloni lebah tergantung pada banyaknya pejantan dan lebah pekerja.
Jumlah stup peternak untuk usaha ternak lebah madu bervariasi, yang paling sedikit 2 kotak lebah (stup) dan yang paling banyak 40 kotak lebah (stup). Secara rinci dapat dilihat Gambar 3.

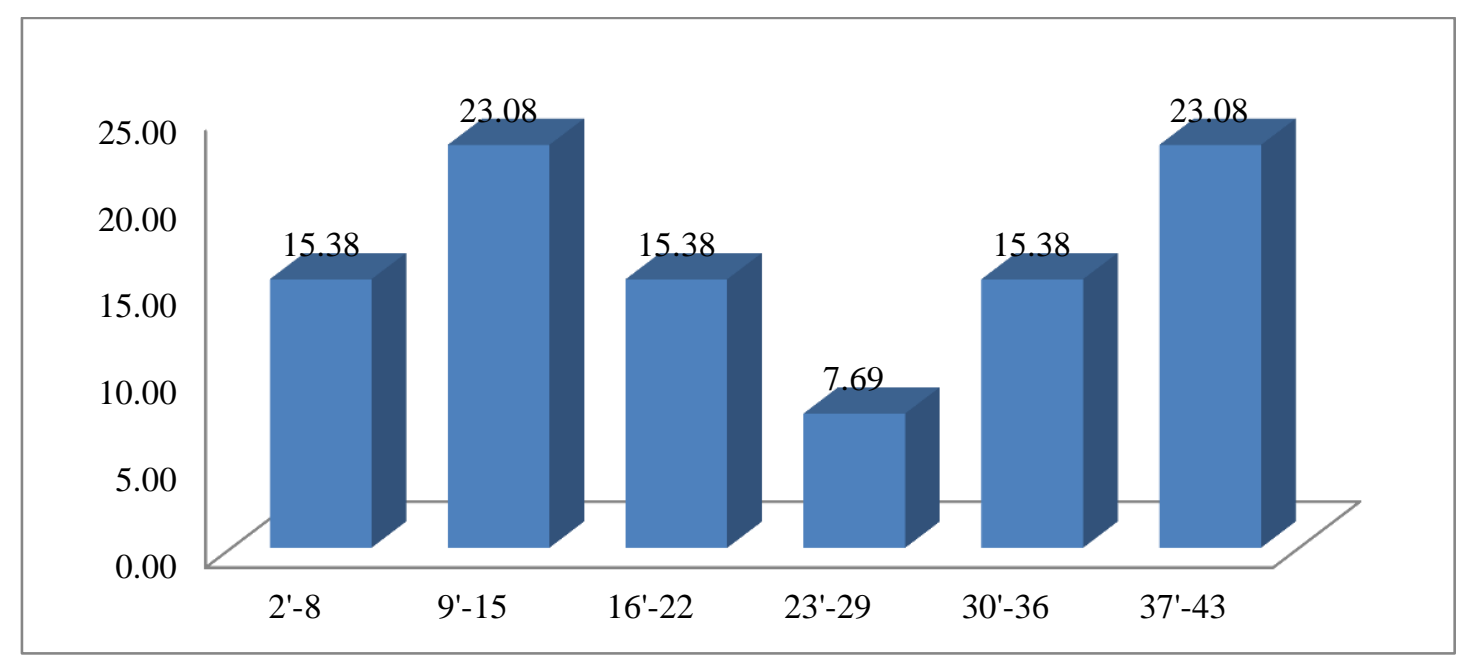

Gambar 3. Jumlah Kotak Lebah (Stup) Peternak Lebah di Kabupaten Kampar, Tahun 2019

Berdasarkan Gambar 3, berjumlah 6 peternak $(23,08 \%)$ memiliki kotak lebah (stup) sebanyak 9-15 kotak lebah (stup) dan 37-43 kotak lebah (stup). Sedangkan peternak yang memiliki kotak lebah paling sedikit 23-29 kotak lebah (stup) berjumlah 2 peternak (7,69\%). Sampai saat ini jumlah stup/sarang lebah madu yang dimiliki para peternak pada umumnya cenderung tetap, bahkan ada beberapa peternak jumlah kotak lebah (stup) mulai berkurang. Salah satu penyebabnya dikarenakan kurangnya pengetahuan dan keterampilan peternak untuk memperbanyak (klonning) sarang lebah. Petani sudah mencoba, namun tingkat keberhasilan rendah. Sementara itu, koloni lebah kelulut di hutan mulai berkurang.

\section{Teknologi Budidaya Madu Kelulut}

Trigona sp./ kelulut/ klanceng/ teuweul/ galo-galo merupakan salah satu serangga sosial yang hidup berkelompok membentuk koloni. Satu koloni lebah antara 300-80.000 ekor lebah (Balai Penelitian dan Pengembangan Teknologi Hasil Hutan Bukan Kayu, 2018). 
Adapun diagram alur budidaya madu kelulut dapat dilihat sebagai berikut:

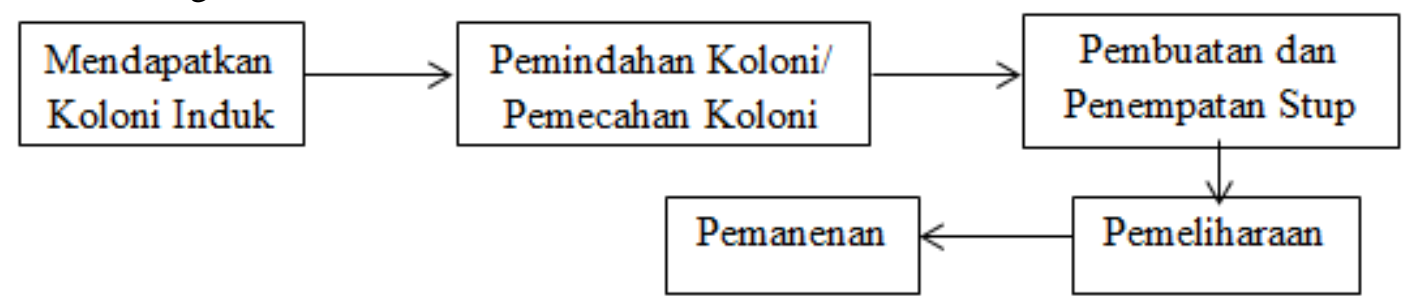

Gambar 4. Alur Budidaya Madu Kelulut

\section{1) Mendapatkan Koloni Induk}

Koloni indukan kelulut dapat dicari melalui pembudidaya lebah kelulut atau melakukan pencarian koloni di hutan dan sekitar kebun (Gambar 5).
2) Pemindahan Koloni/ Pemecahan

Umumnya ruang pada sarang alami relatif sempit. Sehingga untuk keperluan budidaya, koloni yang diperoleh dari alam perlu dipindahkan ke stup yang baru atau modifikasi stup.

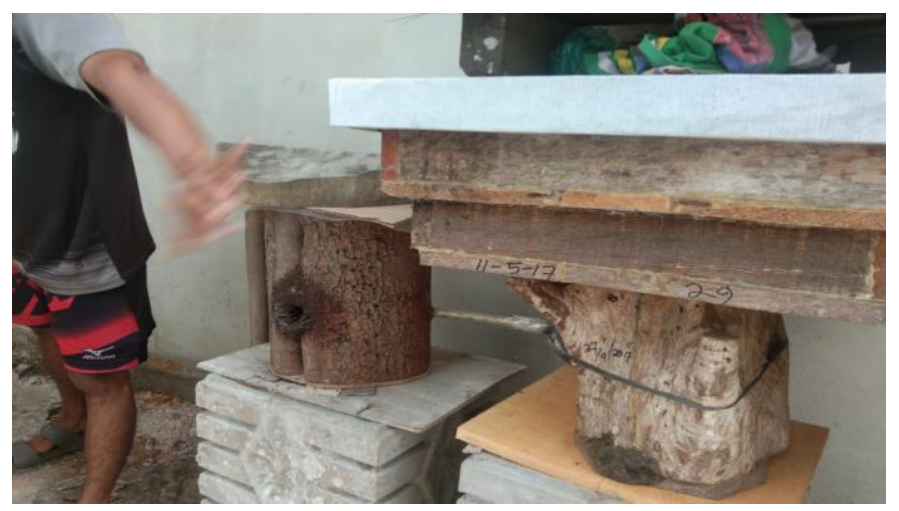

Gambar 5. Pemindahan Kloni Kelulut

3) Pembuatan dan Penempatan Stup

Stup atau rumah lebah dibuat agar lebah aman/nyaman betah tinggal disarangnya dan memudahkan pemanenan produk perlebahan. Stup dibuat dengan memanfaatkan bahan lokal, aman, nyaman dan tahan lama.

a. Bahan stup:umumnya papan kayu kering, tidak berbau, bebas bahan kimia dan memiliki kekuatan/keawetan baik.

b. Stup ditempatkan pada lokasi yang teduh terlindung sinar matahari langsung dan air.

4) Pemeliharaan

Selama proses budidaya lebah kelulut, kegiatan pemeliharaan yang perlu dilakukan adalah:

a. Pembersihan stup dan sekitarnya dari kotoran, untuk menghindari pengganggu lebah datang.

b. Menjaga lebah kelulut dari gangguan serangga lain seperti semut, laba-laba dan tawon liar. Jauhkan dari unggas terutama ayam. c. Pengecekan koloni lebah setiap dua pekan atau setiap bulan untuk memastikan perkebangan dan kesehatannya. Koloni tidak sehat: jumlah sel telur, kantong madu dan kantong pollen tidak bertambah, cenderung menurun jumlah dan kualitasnya.

Pemilihan lokasi merupakan bagian yang tidak kalah pentingnya dalam pengembangan budidaya, selain kondisi iklim beberapa hal yang perlu diperhatikan dalam budidaya lebah Trigona adalah:

a. Tersedia sumber pakan yang memadai: semua jenis tanaman berbunga yang menghasilkan nektar (makanan lebah) dan serbuk sari (makanan anakan lebah) serta menghasilkan getah (untuk membangun dan melindungi sarang) dengan jumlah seimbang.

b. Kebutuhan air tercukupi: Air digunakan oleh lebah untuk menstabilkan suhu di dalam stup dan untuk mengencerkan madu ketika memberi makan larva lebah. Air 
diperoleh dari embun yang nempel di daun atau sumber air lainnya.

c. Jauh dengan pertanian yang menggunakan pestisida: kontaminasi pestisida pada produk perlebahan terutama madu, polen dan propolis akan menurunkan kualitas dan khasiat produk tersebut.

) Pemanenan
Pada kondisi ideal ketika koloni lebah sehat, sumber pakan melimpah dan tidak terdapat gangguan, periode waktu panen per tiga bulan. Sarang yang sudah mulai penuh oleh madu dan bee bread (polen) dapat dilihat dari aktivitas lebahnya yang agresif menyerang (Gambar 6).

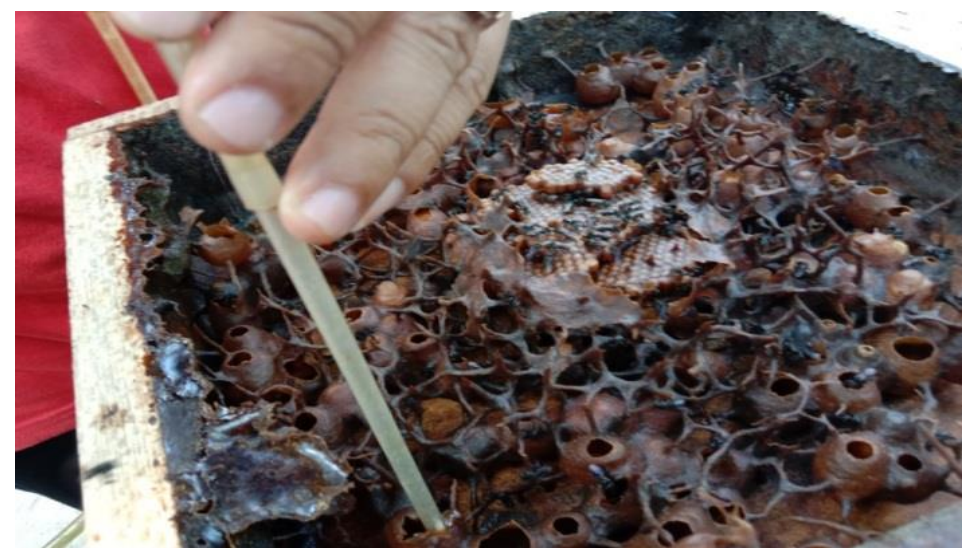

Gambar 6. Panen Madu Galo-Galo dengan Menggunakan Alat Sederhana

$\begin{aligned} & \text { Proses Pengolahan (Agroindustri) Madu } \\ & \text { Kelulut }\end{aligned}$
$\begin{aligned} & \text { Berdasarkan hasil penelitian, proses } \\ & \text { selanjutnya di kemas. Pada tahap pengemasan } \\ & \text { ini madu dapat dialirkan ke kemasan botol }\end{aligned}$
$\begin{aligned} & \text { pengolahan madu kelulut masih bersifat } \\ & \text { tradisional. Madu yang terkumpul dalam }\end{aligned}$

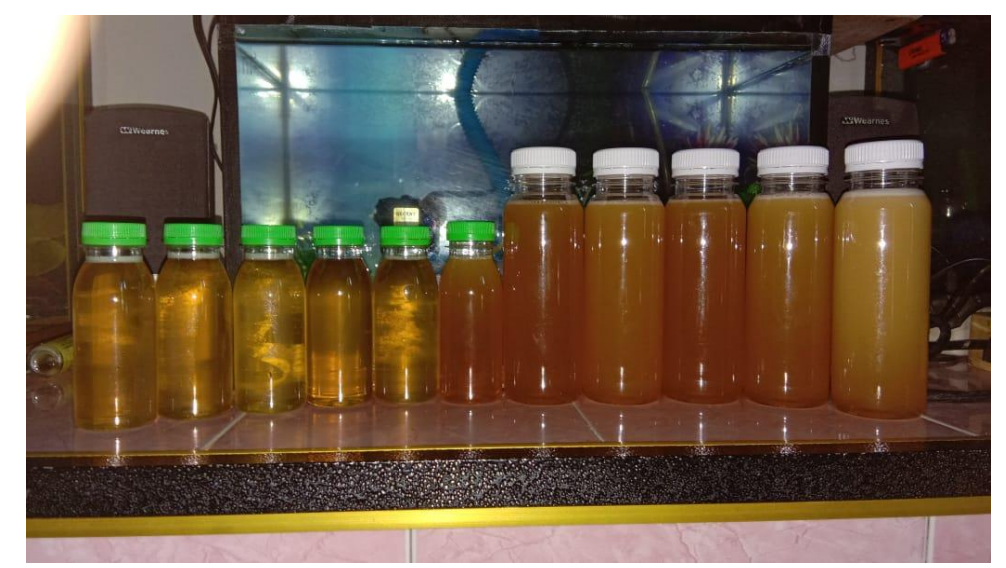

Gambar 7. Madu Galo-Galo Telah Dikemas

Biaya Produksi, Produksi, Pendapatan dan Efisiensi Madu Kelulut

\section{A. Biaya Produksi}

Biaya produksi merupakan keseluruhkan biaya yang dikeluarkan oleh peternak lebah madu, yang dikelompokan menjadi biaya tetap (Fixed Cost) dan biaya tidak tetap (Vriabel Cost).

\section{B. Biaya Tetap (Fixed Cost)}

Dalam usaha peternakan lebah madu, yang termaksud biaya tetap adalah biaya penyusutan stup (kotak lebah), dan penyusutan alat-alat (Pipet untuk panen). Hasil penelitian menunjukkan bahwa rata-rata biaya tetap yang dikeluarkan oleh masing-masing peternak Rp. $154.883,33$. Rincian rata-rata jumlah biaya penyusutan stup dan alat dapat dilihat pada Tabel 2. 
Tabel 2 menunjukkan bahwa biaya tetap terbesar yang dikeluarkan oleh peternak lebah madu adalah penyusutan stup, yaitu mencapai
$(98,65 \%)$ kemudian biaya penyusutan alat (pipet) $1,35 \%$.

Tabel 2. Biaya Penyusutan Stup dan Alat pada Usaha Lebah Madu Kelulut per Orang per Proses Produksi, 2019

\begin{tabular}{cccc}
\hline No & Komponen Biaya & Biaya Rata-Rata & Persentase (\%) \\
\hline 1 & Penyusutan Stup & $152.800,00$ & 98,65 \\
2 & Penyusutan Alat (Pipet) & $2.083,33$ & 1,35 \\
\hline & Jumlah & $154.883,33$ & 100,00 \\
\hline
\end{tabular}

C. Biaya Tidak Tetap (Variable Cost)

Biaya tidak tetap (Variable Cost) merupakan biaya yang dikeluarkan oleh peternak yang meliputi biaya koloni dan botol kosong. Rincian rata-rata jumlah biaya tidak tetap dapat dilihat pada Tabel 3 .

Tabel 3. Biaya Variabel pada Usaha Lebah Madu Kelulut per Orang per Proses Produksi, 2019

\begin{tabular}{cccc}
\hline No & Komponen Biaya & Biaya Rata-Rata & Persentase (\%) \\
\hline 1 & Koloni Dibeli & $300.000,00$ & 90,09 \\
2 & Botol & $33.000,00$ & 9,91 \\
\hline \multicolumn{2}{c}{ Jumlah } & $333.000,00$ & 100,00 \\
\hline
\end{tabular}

Dari Tabel 3, dapat dilihat bahwa biaya tidak tetap yang terbesar adalah biaya pembelian koloni yaitu sebesar Rp. 300.000 $(90,09 \%)$ dan pembelian botol Rp 33.000 $(9,91 \%)$. Pada pakan, lebah kelulut memperoleh pakan dari nektar-nektar bunga di sekitar rumah peternak. Lebah madu tidak membutuhkan pakan tambahan dan obat- obatan sehingga biaya variabel yang dikeluarkan tidak terlalu besar.

Berdasarkan hasil analisis dari setiap komponen biaya tetap dan tidak tetap, diperoleh rata-rata biaya total yang dikeluarkan oleh peternak sebesar Rp. 487.883,33. Rincian rata-rata biaya total produksi dapat dilihat pada Tabel 4.

Tabel 4. Biaya Produksi pada Usaha Lebah Madu Kelulut per Orang per Proses Produksi, 2019

\begin{tabular}{cccc}
\hline No & Jenis Biaya & Biaya Rata-Rata & Persentase $(\%)$ \\
\hline 1 & Biaya Tetap & $154.883,33$ & 31,75 \\
2 & Biaya Tidak Tetap & $333.000,00$ & 68,25 \\
\hline & Jumlah & $487.883,33$ & 100,00 \\
\hline
\end{tabular}

Pada Tabel 4, terlihat bahwa rata-rata biaya tidak tetap lebih besar, yaitu Rp. 333.000 $(68,25 \%)$, sedangkan biaya tetap sebesar Rp $154.883,33(31,75 \%)$ dari seluruh biaya produksi. Hal ini disebabkan karena biaya yang dialokasikan untuk biaya tetap jauh lebih kecil karena komponen biaya yang secara nyata dikeluarkan peternak alat dan sistem pemeliharaan yang masih tradisional sehingga usaha kecil lebah madu tidak membutuhkan tenaga kerja yang banyak.

\section{Produksi}

Jenis produksi yang dapat dihasilkan oleh lebah madu kelulut selain madu adalah pollen, royal jelly, malam (lilin lebah), dan propolis. Namun hasil penelitian ini menunjukkan bahwa semua peternak madu hanya memproduksi madu saja. Rata-rata produksi madu pada saat musim berbunga 20,04 liter dan pada saat tidak musim berbunga
7,79 liter. Ketika musim bunga, produksi madu bisa mencapai 800 ml-1 liter/kotak madu/bulan, sedangkan tidak musim bunga $200 \mathrm{ml}-500 \mathrm{ml} /$ kotak madu/bulan. Produksi madu pada nektar bunga berbeda dengan produksi madu pada nektar tanaman buah. Pada penelitian Pasaribu dkk (2017), produksi madu pada tanaman stroberi, rata-rata 3,96 liter/stup/tahun atau $5,54 \mathrm{~kg} / \mathrm{stup} /$ tahun. Menurut (Saepudin, 2010) produksi optimal sekitar 5-10 kg/koloni/tahun, pada produksi lebah madu tanaman kopi.

\section{E. Pendapatan}

Harga jual madu di lokasi penelitian berdasarkan pada kemasan/botol. Per botol 100 $\mathrm{ml}$, dijual dengan harga Rp. 100.000. Namun ada beberapa peternak yang menjual dengan satuan liter, harga per liter Rp. 800.000. Secara rinci, pendapatan peternak dapat dilihat pada Tabel 5. 
Tabel 5. Rata-Rata Pendapatan Peternak Madu Kelulut per Orang per Panen per Kotak Lebah dalam satuan Mililiter, 2019

\begin{tabular}{|c|l|c|}
\hline No & \multicolumn{1}{|c|}{ Uraian } & Nilai (Rp) \\
\hline \multirow{2}{*}{1} & Pendapatan Kotor & $3.461 .538,46$ \\
& Musim Bunga & $1.346 .153,85$ \\
\cline { 2 - 2 } & Musapan Bersih & $2.973 .655,13$ \\
2 & Pendapatan & $858.270,52$ \\
\hline & Musim Bunga & \\
& Musim Tidak Berbunga & \\
\hline
\end{tabular}

Pendapatan bersih usaha membudidaya lebah madu kelulut diperoleh dari hasil pengurangan antara pendapatan kotor yang diperoleh peternak dengan total biaya produksi yang dikeluarkan. Rata-rata pendapatan bersih pada musim bunga sebesar Rp 2.973.655,13 per orang per panen per kotak lebah dan pada saat tidak musim bunga Rp 858.270,52 per orang per panen per kotak lebah. Rata-rata pendapatan bersih yang diterima oleh peternak ini relatif tinggi bila dibandingkan dengan besarnya rata-rata biaya produksi yang dikeluarkannya. Hal ini disebabkan oleh harga jual madu yang tinggi, sementara biaya produksi yang dikeluarkan oleh peternak relatif rendah, yaitu untuk biaya penyusutan kotak lebah (stup), dan penyusutan alat, dan biaya variabel (koloni dan botol).

\section{F. Efisiensi}

Suatu usaha mempunyai efisiensi yang tinggi bila dalam pengelolaannya mampu menekan biaya-biaya produksi yang dikeluarkan dan dapat menghasilkan produksi yang tinggi dengan harga yang baik. Efisiensi usahatani madu, pada saat musim bunga 7,09 dan pada saat musim tidak berbunga 2,76. Hal tersebut menunjukkan bahwa budidaya usahatani madu kelulut sudah efisien. Senada dengan penelitian Purwanto (2015), efisiensi usahatani madu di Kabupaten Banyumas sudah efisien bernilai 9,16.

\section{Pemasaran Madu Kelulut}

Pemasaran menjadi ujung tombak dalam peningkatan usaha. Pemasaran yang efektif dapat dicapai dengan promosi dan membentuk jaringan usaha yang dapat memudahkan penyebaran informasi (Situmorang, 2008).

Madu galo-galo mempunyai potensi yang baik untuk dikembangkan Meskipun madu galo-galo ini tergolong produk baru, namun permintaan sangat banyak. Madu ini berkhasiat cukup tinggi karena memiliki kandungan propolis sebagai antibiotik alami untuk mengobati penyakit diare, radang tenggorokan, menyeimbangkan kadar kolesterol dalam darah dan infeksi. Madu ini juga mulai dilirik oleh dunia industri, seperti industri makanan dan minuman bahkan oleh industri kecantikan.

Untuk saat ini, peternak hanya mampu menjual madu ke kota Pekanbaru (belum bisa menjual ke luar propinsi). Hal ini disebabkan belum memiliki merek dan masih dalam kemasan botol plastik. Sehingga adanya keraguan bagi pembeli terhadap keaslian produk tersebut.

\section{KESIMPULAN}

1) Karakteristik peternak dengan kategori umur produktif; pendidikan SD-Sarjana; pengalaman beternak 1-6 tahun. Profil usaha dirintis pada tahun 2016, dengan nama kelompok madu galo-galo Kuok Lestari, anggota kelompok berjumlah 26 orang.

2) Teknologi budidaya terdiri dari mendapatkan koloni induk; pemindahan koloni/pemecahan koloni; pembuatan dan penempatan stup; pemeliharaan dan pemanenan.

3) Proses pengolahan bersifat tradisional. Madu yang terkumpul dalam wadah botolbotol penampung madu, selanjutnya dikemas. Pada tahap pengemasan ini madu dapat dialirkan ke kemasan botol sesuai dengan volume ukuran kemasan (100 ml $200 \mathrm{ml})$

4) Usaha madu kelulut membutuhkan biaya produksi Rp. 487.883,33/proses produksi; dengan rata-rata produksi madu pada saat musim berbunga 20,04liter dan pada saat tidak musim berbunga 7,79 liter. Rata-rata pendapatan bersih pada musim bunga sebesar Rp 2.973.655,13 per orang per panen per kotak lebah dan pada saat tidak musim bunga Rp 858.270,52 per orang per panen per kotak lebah. 
5) Pemasaran madu kelulut hanya menjual ke kota Pekanbaru (belum bisa menjual ke luar propinsi).

\section{DAFTAR PUSTAKA}

Badan Penelitian dan Pengembangan Kehutanan. Balai Penelitian Teknologi Serat Tanaman Hutan. 2018. Roadmap Penelitian Perlebahan. Jakarta.

Hapsari, H., E. Djuwendah dan Y. Supriyadi. 2018. Optimalisasi Manajemen Usaha Lebah Madu untuk Meningkatkan Pendapatan Keluarga (Kasus pada Kelompok Tani Sunda Mukti, Desa Cilengkrang, Kecamatan Cilengkrang, Kabupaten Bandung). Jurnal Aplikasi Ipteks untuk Masyarakat, 7 (1): 46-50.

Hernanto, F. 1996. Ilmu Usaha Tani. Penebar Swadaya, Jakarta.

Kementrian Kehutanan. 2012. Rancangan Undang-Undang Tentang Konservasi Keanekaragaman Hayati (Konservasi Kehati). Kementrian Lingkungan Hidup dan Kehutanan. Jakarta.

Mosher, A. T. 1977. Menggerakkan dan Membangun Pertanian Syarat-syarat Pokok Pembangunan dan Modernisasi. CV. Yasaguna, Jakarta.

Mubyarto. 1989. Pengantar Ekonomi Pertanian. Lembaga Penelitian, Pendidikan dan Penerangan Ekonomi dan Sosial (LP3ES), Jakarta.

Mubyarto. 1986. Pengantar Ekonomi Pertanian. LP3ES, Jakarta.

Ngamel, A. K. 2012. Analisis Finansial Usaha Budidaya Rumput Laut dan Nilai Tambah Tepung Karaginan di Kecamatan Kei Kecil, Kabupaten Maluku Tenggara. Jurnal Sains Terapan, 2(1): 68-83.

Pasaribu, R., H. D. Putranto dan Sutriyono. 2017. Perbandingan Produksi Lebah Madu Apis cerana pada Dua Sistem Integrasi yang Berbeda di Kabupaten Rejang Lebong. Jurnal Sains Peternakan Indonesia, 12(4): 432-443.

Purwanto. 2015. Analisis Efisiensi Ekonomi Usahatani Lebah Madu Di Desa Kalisari Kecamatan Cilongok Kabupaten Banyumas. Agritech, 17(2): 106-112.

Saepudin, R. 2010. Peningkatan Produktivitas Lebah Madu Melalui Penerapan Sistem Integrasi dengan Kebun Kopi. Jurnal
Sains Peternakan Indonesia, 6(2): 115124.

Situmorang, P. 2008. Pengantar Pasar Modal. Edisi Pertama. Mitra Wacana Media, Jakarta.

Sumoprastowo, R. M dan S. R. Agus. 1993. Beternak Lebah Madu Modern. Bhratara, Jakarta. 
